\title{
Transferring Cucumber Mosaic Virus-White Leaf Strain Coat Protein Gene into Cucumis melo L. and Evaluating Transgenic Plants for Protection against Infections
}

\author{
Carol Gonsalves, Baodi Xue, Marcela Yepes, Marc Fuchs, Kaishu Ling, and Shigetou Namba ${ }^{1}$ \\ Department of Plant Pathology, Cornell University, New York State Agricultural Experiment Station, \\ Geneva, NY 14456
}

Paula Chee $^{2}$ and Jerry L. Slightom²
Molecular Biology Unit 7242, The Upjohn Company, 301 Henrietta Street, Kalamazoo, MI 49007

Dennis Gonsalves

Department of Plant Pathology, Cornell University, New York State Agricultural Experiment Station, Geneva, NY 14456

Additional index words. coat protein mediated-protection, gene gun, ploidy, regeneration, somaclonal variation, tissue
culture, transformation

Abstract. A single regeneration procedure using cotyledon explants effectively regenerated five commercially grown muskmelon cultivars. This regeneration scheme was used to facilitate gene transfers using either Agrobacterium tumefaciens (using 'Burpee Hybrid' and 'Hales Best Jumbo') or microprojectile bombardment (using 'Topmark') methods. In both cases, the transferred genes were from the T-DNA region of the binary vector plasmid pGA482GG/cp cucumber mosaic virus-white leaf strain (CMV-WL), which contains genes that encode neomycin phosphotransferase II (NPT II), $\beta$-glucuronidase (GUS), and the CMV-WL coat protein (CP). Explants treated with pGA482GG/cpCMV-WL regenerated shoots on Murashige and

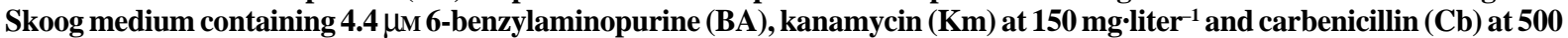
mg-liter-1. Our comparison of $A$. tumefaciens- and microprojectile-mediated gene transfer procedures shows that both methods effectively produce nearly the same percentage of transgenic plants. $R_{0}$ plants were first tested for GUS or NPT II expression, then the polymerase chain reaction (PCR) and other tests were used to verify the transfer of the NPT II, GUS, and CMV-WL CP genes. This analysis showed that plants transformed by $A$. tumefaciens contained all three genes, although cotransferring the genes into bombarded plants was not always successful. $R_{1}$ plants were challenge inoculated with CMV-FNY, a destructive strain of CMV found in New York. Resistance levels varied according to the different transformed genotypes. Somaclonal variation was observed in a significant number of $\mathbf{R}_{\mathbf{0}}$ transgenic plants. Flow cytometry analysis of leaf tissue revealed that a significant number of transgenic plants were tetraploid or mixoploid, whereas the commercial nontransformed cultivars were diploid. In a study of young, germinated cotyledons, however, a mixture of diploid, tetraploid, and octoploid cells were found at the shoot regeneration sites.

Cucurbits, such as melons, cucumbers, pumpkins, squash, and gourds, are consumed in large quantities throughout the world. More than 58 million metric tons of cucurbits were produced in 1990, with nearly 54\% of the world's crop grown in Asia and >26\% in Europe, with Africa and North, Central, and South America comprising the bulk of the remaining portion (Food and Agriculture Organization, 1990).

Cucumber mosaic virus (CMV) is found virtually everywhere cucurbits are grown, and it is most active in temperate and subtropical zones. It has a host range of $>800$ plant species, is transmitted by aphids in a nonpersistent manner, and its visible symptoms include mosaic and stunting of growth (Palukaitis et al., 1992). Worldwide, CMV is one of the five major viruses affecting field-grown vegetables (Tomlinson, 1987). CMV is one of the most important cucurbit and pepper viruses in New York (T.Zitter,

\footnotetext{
Received for publication 9 Feb. 1993. Accepted for publication 21 June 1993. We gratefully thank R. Provvidenti and R.W. Robinson for advice, J.C. Sanford for use of a helium-driven particle accelerator, T. Zitter for the CMV-FNY strain, and N. $\mathrm{Lu}$ and S.E. Ecker-Day for excellent technical assistance. Mention of a trademark, proprietary product, or vendor does not imply its approval to the exclusion of other products or vendors that also may be suitable. The cost of publishing this paper was defrayed in part by the payment of page charges. Under postal regulations, this paper therefore must be hereby marked advertisement solely to indicate this fact. ${ }^{1}$ Permanent address: Laboratory of Plant Pathology, Faculty of Agriculture, Univ. of Tokyo, Bunkyo-Ku, Tokyo, Japan.
}

personal communication), where the virus is routinely the first to occur in cucurbits due to early insect vectoring from perennial weed hosts (Banik and Zitter, 1990).

Resistance to CMV has been reported for some cucurbits and incorporated into a number of species (Pierce and Wehner, 1990; Robinson et al., 1982); CMV-resistant cucumbers are now widely grown (Munger, 1985; Wehner and Robinson, 1991). Resistance to CMV in muskmelons was identified as early as 1943 (Enzie, 1943), but, as far as we know, no commercial cultivars are currently available. Recently, studies have shown that genetically engineered plants expressing a plant viral coat protein $(\mathrm{CP})$ gene can resist infection by the homologous and in some cases heterologous viruses (Beachy et al., 1990; Ling et al., 1991; Namba et al., 1992; Stark and Beachy, 1989). This promising alternate approach to developing virus-resistant plants, known as CP-mediated protection (CPMP), has been applied to some commercial crops in extensive field trials. Among vegetable crops, practical application of CPMP has been demonstrated in a 3-year field trial of transgenic cucumbers containing the $\mathrm{CP}$ gene of $\mathrm{CMV}-\mathrm{C}$ strain (Gonsalves et al., 1992). This study showed that CMV resistance in transgenic cucumbers is comparable to that in 'Marketmore', the cucumber industry's standard cultivar for CMV resistance.

The family Cucurbitaceae meets the two major requirements for obtaining transgenic plants. First, tissue-culture procedures have been established for several species. These include crops 
such as melon (Chee, 1991a; Dirks and Van Buggenum, 1989; Kathal et al., 1989; Moreno et al., 1985; Oridate and Oosawa, 1986), squash (Chee, 1991b; Chee, 1992), pumpkin (Jelaska, 1974), and cucumber (Chee, 1990a). Second, cucurbit cells are susceptible to infection by Agrobacterium tumefaciens or A. rhizogenes and penetration by microprojectiles, thus enabling the transfer of genetic material into the genome of these plant species. Trulson et al. (1986) used A. rhizogenes to insert the NPT II gene into cucumber roots and regenerated plants from transformed hypocotyls. Using A. tumefaciens, Yoshioka et al. (1992) transferred the CMV-Y strain CP gene into melon; Chee (1990b) transformed cucumber cotyledons with neomycin phosphotransferase II (NPT II) and also with NPT II, $\beta$-glucuronidase (GUS), and CMV-C CP genes (Chee and Slightom, 1991). Fang and Grumet (1990) and Dong et al. (1991) transformed melon cotyledons with NPT II and with NPT II, GUS, and dihydrofolate reductase genes, respectively. Finally, NPT II-transformed cucumber plants were obtained by microprojectile bombardment of embryogenic callus (Chee and Slightom, 1992).

This paper describes the genetic transfer of an economically useful CP gene [CMV-white leaf (WL) strain] into several muskmelon cultivars (Burpee Hybrid, Hales Best Jumbo, and Topmark). This is also the first report on melon transformation comparing microprojectile bombardment with A. tumefaciens-mediated transformation. Somaclonal variation of leaves, stems, and flowers was observed in $\mathrm{R}_{0}$ plants. In $\mathrm{R}_{1}$ plants, some leaf clustering, fanshaped leaves, and short internodes were observed, a result indicating that morphologic abnormalities were sexually transmitted to progeny. Most of the transgenic plants were tetraploid or mixoploid, as confirmed by flow cytometry analysis. Progeny from high CPexpressing 'Hales Best Jumbo' $\mathrm{R}_{0}$ lines that were inoculated with CMV-FNY isolate had delayed symptom expression, and some plants escaped infection. Similarly, inoculated progeny of an $\mathbf{R}_{0}$ 'Topmark' line that expressed CP had delayed symptom expression, but progeny from non-CP-expressing $\mathrm{R}_{0}$ lines of 'Topmark' and 'Burpee Hybrid' had no resistance at all.

\section{Cotyledon}

\section{Preparation}
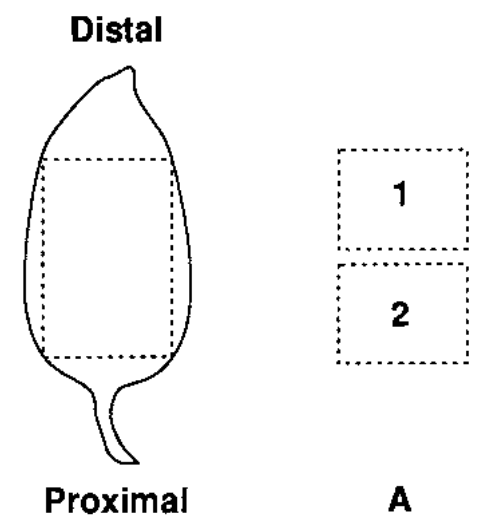

A

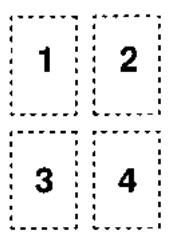

B

Fig. 1. Schematic illustration of Cucumis melo cotyledon explant and preparation for shoot regeneration and transformation studies. Preparation A was used for microprojectile bombardment: A-2 for apolar orientation and A-1 and A-2 for flat orientation. Preparation B was used in Agrobacterium tumefaciens transformation and shoot regeneration studies. In this report, distal explants refer to A-1, B-1, or B-2 and proximal explants refer to A-2, B-3, or B-4. Note that each cut piece also has a distal edge and a proximal edge in addition to two sides.

\section{Materials and Methods}

\section{Plant material}

Seeds of 'Burpee Hybrid', 'Hales Best Jumbo', 'Harvest Queen', 'Hearts of Gold', and 'Topmark' muskmelon, originally from commercial sources, were obtained from the New York State Agricultural Experiment Station seed laboratory. Seeds were soaked in tap water for $15 \mathrm{~min}$ and seed coats were removed before sterilization in $15 \%(\mathrm{v} / \mathrm{v})$ Clorox ( $5.25 \%$ sodium hypochlorite) for $15 \mathrm{~min}$. After four rinses in sterile distilled water, seeds were germinated on moist filter paper in sterile Petri dishes and maintained in the dark. Four days later, cotyledons were trimmed along all edges (being careful to cut off the proximal end 1 to $2 \mathrm{~mm}$ from its juncture with the hypocotyl) and cut into smaller pieces (Fig. 1).

\section{Plant culture medium}

Regeneration medium (RM) contained Murashige and Skoog (MS) salts and vitamins (Murashige and Skoog, 1962) and $4.4 \mu \mathrm{M}$ 6-benzylaminopurine (BA) (Dirks and Van Buggenum, 1989). Elongation medium (EM) consisted of MS medium with $0.22 \mu \mathrm{M}$ BA (Chee, 1991a) and rooting medium contained MS medium with $2 \%$ sucrose (Dirks and Van Buggenum, 1989). Unless otherwise stated, all media were supplemented with $3 \%$ sucrose and $0.8 \%$ agar; the $\mathrm{pH}$ was adjusted to 5.7 before autoclaving at $121 \mathrm{C}$ for $15 \mathrm{~min}$. After autoclaving, carbenicillin $(\mathrm{Cb})$ at $500 \mathrm{mg} \cdot \mathrm{liter}^{-1}$ was added to all media to control endogenous bacteria present in cotyledons. Cultures were incubated under white fluorescent lamps at $76 \mu \mathrm{mol} \cdot \mathrm{m}^{-2} \cdot \mathrm{s}^{-1}$ (photometer model LI-185B; LI-COR, Lincoln, Neb.), with a 16 -h photoperiod. The room temperature was $28 \pm 2 \mathrm{C}$.

Selective RM and EM containing kanamycin $(\mathrm{Km})$ at 150 mg.liter ${ }^{-1}$ were used for treated explants in A. tumefaciens- and microprojectile-mediated transformation experiments. A few nontreated controls were grown on selective media to monitor $\mathrm{Km}$ toxicity level on the explants, and other nontreated controls were grown on media containing $\mathrm{Cb}$ at $500 \mathrm{mg} \cdot \mathrm{liter}^{-1}$ to monitor the effect of this antibiotic on regeneration. Shoots recovered on selective medium were rooted in rooting medium with or without $\mathrm{Km}$ at $50 \mathrm{mg} \cdot \mathrm{liter}^{-1}$.

\section{Plant regeneration}

All explants were first kept in the dark for 3 days on nonselective RM. Thereafter, nontreated controls were maintained on selective or nonselective media, as described above, and treated explants were moved to selective media. Explants were oriented adaxially onto RM and moved to the light. After 2 to 3 weeks, sectors of regenerated shoots were excised and subcultured on EM for another 2 to 3 weeks. Then, explants with elongating shoots were divided into smaller clusters and transferred to either solid or liquid EM. Explants on liquid medium were cultured in jars on two layers of filter paper and maintained on shelves without agitation. Fresh medium $(20 \mathrm{ml})$ was added at $\approx 2$-week intervals. Shoots $(0.5$ to $1 \mathrm{~cm}$ ) were harvested after 10 to 14 days for cultures in liquid EM medium and after 2 to 3 weeks (after the second transfer of cultures to EM) for cultures in solid medium. Excised shoots rooted in rooting medium in 2 to 3 weeks.

Plants were potted in a nonsterile mix of 2 Terra-Lite (Grace Sierra, Milpitas, Calif.) vermiculite : 1 Agway (Syracuse, N.Y.) all-purpose potting soil and capped with $20-\mathrm{cm}$ tall plastic bags to avoid plant dessication. After 2 to 3 days, a $2.5-\mathrm{cm}$ vent was cut at the top of the bag and gradually enlarged over the next 3 days. Fully opened plastic bags were removed after plants were acclimated to the greenhouse. The temperature was kept at $25 \pm 2 \mathrm{C}$ with natural 
daylight, and sodium lamps were used to stimulate growth when needed. Producing potted plants from regenerated shoots required 2 to 3 months.

\section{Agrobacterium tumefaciens-mediated transformation}

The disarmed A. tumefaciens strain C58Z707 (Hepburn et al., 1985 ) containing the binary plasmid pGA482GG/cpCMV-WL 514 (Namba et al., 1991), which includes CMV-WL CP, GUS, and NPT II genes, was used for transformation. 'Burpee Hybrid', 'Hales Best Jumbo', and 'Topmark' were selected for A. tumefaciens transformation. Each cotyledon from 3- to 4-day old germinated seeds was trimmed and cut into four pieces (Fig. 1B), then soaked 25 to $30 \mathrm{~min}$ in an overnight bacterial culture that was grown in Kado's 523 medium (Kado et al., 1972) containing Km at $50 \mu \mathrm{g} \cdot \mathrm{ml}^{-1}$ and gentamycin $(\mathrm{Gm})$ at $60 \mu \mathrm{g} \cdot \mathrm{ml}^{-1}$. This culture was diluted with half-strength MS salts ( $\mathrm{pH}$ 5.7) to obtain an OD $560 \mathrm{~nm}$ reading of $\approx 0.4$. Inoculated cotyledon pieces were blotted dry and placed abaxially or adaxially onto RM in the dark for 3 days of cocultivation. Shoots were regenerated as described above.

\section{Microprojectile-mediated transformation}

'Topmark' was used for microprojectile transformation experiments. Before bombardment, cotyledons were cut in half and either the proximal explants (Fig. 1A-2) were oriented vertically in the medium in an apolar position or both proximal and distal explants (Fig. 1 A-1 and A-2) were oriented in a horizontal (flat) position with the adaxial surface facing up.

Each plate contained 25 explants embedded in the central 2.5 $\mathrm{cm}^{2}$ of $100 \times 25-\mathrm{mm}$ Petri plates containing RM with $1 \%$ agar. Plasmid DNA was prepared according to the protocol of Sambrook et al. (1989). Protocols described by Sanford et al. (1992) were used to coat tungsten particles with DNA, set up experimental parameters, and fire the particle gun. Each plate was shot once using a helium-driven particle accelerator set at 91 or $141 \mathrm{~kg} \cdot \mathrm{m}^{-2}$ at macroprojectile flight distances of 1 and $0 \mathrm{~cm}$, respectively, to deliver tungsten particles (M-10; Sylvania, Towanda, Pa.) from a 2.54-cm Kapton (Du Pont, Wilmington, Del.) membrane $0.06 \mathrm{~mm}$ thick into the plant tissue over a distance of $12.3 \mathrm{~cm}$.

The microprojectile experiment consisted of three treatments in which explants were 1) bombarded with pGA482GG/cpCMVWL DNA and maintained on selective media, 2) bombarded with buffer-coated particles and maintained on selective media, or 3) bombarded with buffer-coated particles and regenerated on media with $\mathrm{Cb}$ added. After bombardment, explants were kept in the dark for 3 days, then regenerated as described above.

\section{Characterization of regenerated plants}

A number of tests were conducted to detect transgenic plants. Before characterization, young leaf tissue from the first or second leaf below the growing tip of greenhouse-grown A. tumefacienstransformed plants was cut transversely into strips, plated onto Luria-Bertani (LB) medium (Sambrook et al., 1989) containing $\mathrm{Km}$ at $50 \mu \mathrm{g} \cdot \mathrm{ml}^{-1}$ and $\mathrm{Gm}$ at $60 \mu \mathrm{g} \cdot \mathrm{ml}^{-1}$, and observed to determine whether residual Agrobacteria were present.

GUS assays. The X-gluc histochemical assay (Jefferson, 1987; McCabe et al., 1989) was used to detect GUS expression in longitudinal sections of shoot primordia and in leaves of plants produced in the A. tumefaciens-mediated experiments. Tissue was immersed in $250 \mu$ l of substrate in an eppendorf tube and incubated overnight at $37 \mathrm{C}$. If the blue stain was not clearly visible, microscopic observation or a bleach treatment of $4 \mathrm{~h}$ to overnight in $95 \%$ ethanol facilitated the readings. In the microprojectile experiment, cotyledons were additionally assayed for transient expression 5 days after bombardment. The 4-methylumbelliferyl $\beta$-D-glucuronide (MUG) substrate assay was based on the method described by Jefferson (1987). Samples were ground in extraction buffer at 1:7 dilution, and $50 \mu \mathrm{l}$ each of sample and MUG substrate were dispensed into duplicate microtiter plates. After $4 \mathrm{~h}$, one plate was screened for fluorescence under ultraviolet light . The other plate was screened after overnight incubation.

Leaf callus assay. Leaf callus assay was used to determine whether plants expressed the NPT II gene. Tissue was taken directly from tissue culture or from the youngest expanded leaf of plants that had been transferred to soil. Greenhouse tissue was soaked for $15 \mathrm{~min}$ in $15 \%$ (v/v) Clorox (5.25\% sodium hypochlorite) plus one drop Tween 20 (per $500 \mathrm{ml}$ ), rinsed three times in sterile distilled water, and blotted dry. They were then cut transversely into strips and placed adaxially into Petri dishes on callusinduction medium [MS medium, 5.4 $\mu \mathrm{M}$ napthaleneacetic acid (NAA), $2.6 \mu \mathrm{M} \mathrm{BA}$, agar $8 \mathrm{~g} \cdot$ liter $^{-1}, \mathrm{pH}$ 5.7] containing $\mathrm{Km}$ at 200 $\mathrm{mg} \cdot$ liter $^{-1}$ and $\mathrm{Cb}$ at $500 \mathrm{mg} \cdot \mathrm{liter}^{-1}$. Leaf strips that produced abundant callus were rated positive for NPT II gene expression.

Polymerase chain reaction (PCR). Plasmid DNA, pGA482GG/ cpCMV-WL 5-14 (Namba et al., 1991), was extracted from inoculated Escherichia coli DH5a cells by the alkaline maxi-prep procedure and further purified on $\mathrm{CsCl}$ gradients (Sambrook et al., 1989). Total crude plant DNA was extracted from young leaves of melon plants according to the procedure described by Dellaporta et al. (1985). Two oligomer primers, complementary to the $5^{\prime}$ and $3^{\prime}$ end of the CMV-WL CP gene, were used to detect the presence of the CP gene (Namba et al., 1991). Oligomer primers to detect GUS and NPT II genes were also used. Each PCR reaction was carried out according to the instructions provided by the manufacturer (Perkin Elmer, Norwalk, Conn.) using 1 to $2 \mu \mathrm{g}$ of template DNA, $150 \mathrm{ng}$ of the primers, and 2.5 units of Taq DNA polymerase per reaction.

Enzyme-linked immunosorbent assay (ELISA) for CP detection . ELISAs were conducted by the procedure described by Namba et al. (1991) to detect CMV-WL CP in transgenic plants using antibodies to CMV-WL (Edwards and Gonsalves, 1983). Leaves were ground in extraction buffer at 1:5 dilution. Coating immunoglobulins were used at $1 \mu \mathrm{g} \cdot \mathrm{ml}^{-1}$ and enzyme-conjugated immunoglobulins were used at a 1:500 dilution.

ELISA for NPT II detection. Greenhouse plants were screened using ELISA (5 Prime-3 Prime, Boulder, Colo.) to detect the NPT II protein in crude cellular leaf extracts.

Western blot analysis. Total soluble proteins were extracted from young leaves, subjected to sodium dodecyl sulfate-polyacrylamide gel electrophoresis (Laemmli, 1970), and transferred onto polyvinylidene fluoride immobilon membranes (Millipore, Bedford, Mass.). The membranes were incubated overnight at $4 \mathrm{C}$ with specific polyclonal antibodies raised against purified virus particles and for $2 \mathrm{~h}$ at 37C with goat antirabbit antibodies conjugated to alkaline phosphatase (Sigma Chemical Co., St. Louis). Substrates were nitroblue tetrazolium chloride at 100 $\mu \mathrm{g} \cdot \mathrm{ml}^{-1}$ and 5-bromo-4-chloro-3-indolyl phosphate at $50 \mu \mathrm{g} \cdot \mathrm{ml}^{-1}$.

Ploidy determination. The ploidy level and total nuclear DNA content (C-value) of leaf and cotyledon samples were analyzed by flow cytometry following the procedure of Arumuganathan and Earle (1991). The samples were run on an EPICS Profile 753 flow cytometer at the Cornell Univ. Biotechnology Center.

Morphology. $\mathrm{R}_{0}$ transgenic plants were monitored for variations in leaf, stem, and flower morphology and compared with plants grown from commercial seed.

\section{Infectivity tests}

Test plants were inoculated at the one- to two-true-leaf stage. 
Inoculum consisted of leaf tissue of 'President' squash inoculated 7 days previously with CMV-FNY (Zitter and Gonsalves, 1991) and ground in $0.01 \mathrm{~m}$ phosphate buffer, $\mathrm{pH} 7.0$, at a 1:50 $\left(\mathrm{g} \cdot \mathrm{ml}^{-1}\right)$ dilution. Extracts were applied to cotyledons and leaves that were dusted with corundum. Melon plants were scored positive for infection when yellow lesions or mosaic symptoms appeared on young, noninoculated leaves. Chenopodium quinoa was used as the local lesion indicator plant.

\section{Results}

Melon regeneration using different cultivars. 'Burpee Hybrid', 'Hales Best Jumbo', 'Hearts of Gold', 'Harvest Queen', and 'Topmark' were successfully regenerated on Dirks and Van Buggenum (1989) melon regeneration medium. When 3-day germinated cotyledons (32 to 40 explants/cultivar) were used, the

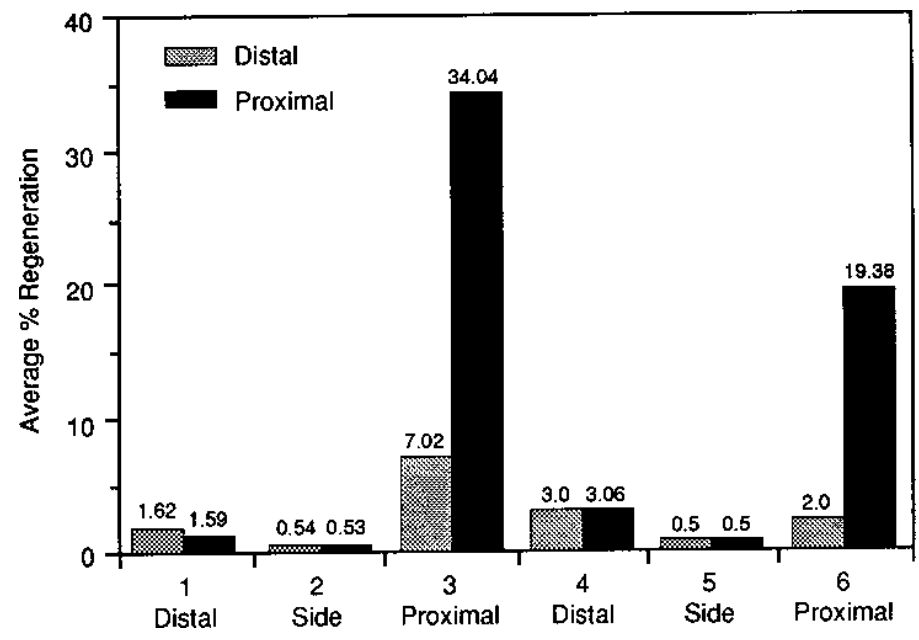

Fig. 2. Location and relative frequency of shoot regeneration, summarized as average percentage regeneration for 'Burpee Hybrid', 'Hales Best Jumbo', 'Harvest Queen', 'Hearts of Gold', and 'Topmark' muskmelon. Six hundred explants (120/cultivar) were analyzed for regeneration along their proximal, distal, and side edges (Fig. 1). In columns 1 to 3,80 explants/cultivar were cut as in Fig. 1, preparation A; in columns 4 to 6, 40 explants/cultivar were cut as in Fig. 1, preparation B.

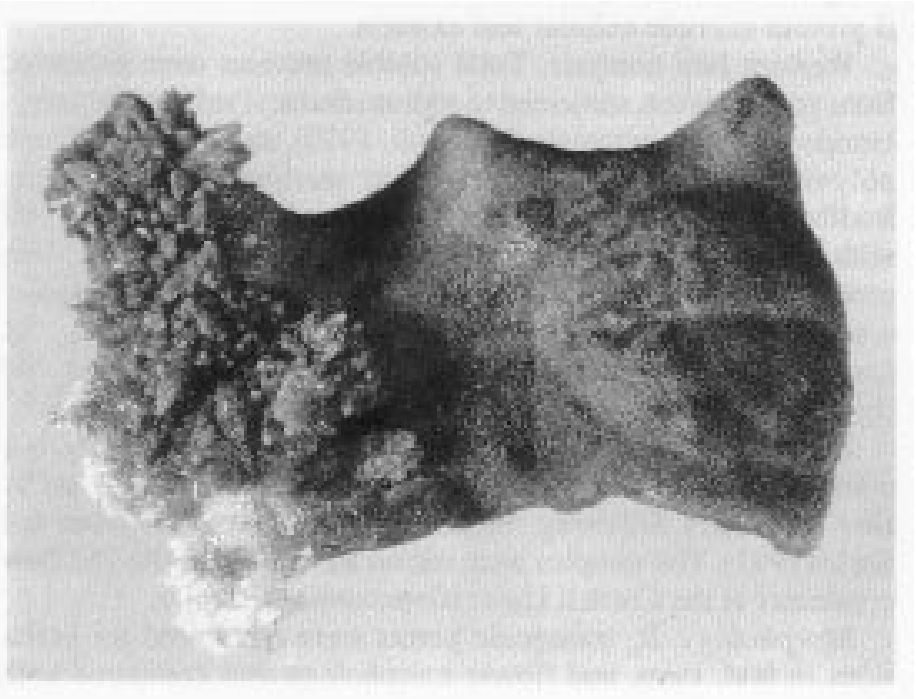

Fig. 3. Shoot primordia form a tight mass primarily along the proximal edge of cotyledon pieces taken from the segments A-2, B-3, and B-4 (Fig. 1) of germinated cotyledons. Shown here, 'Topmark' muskmelon regenerating shoots 3 weeks after bombardment with DNA-coated tungsten particles. regeneration rates, based on the number of regenerating explants per total explants tested for each cultivar ,were 'Burpee Hybrid', 14\%; 'Hales Best Jumbo', 69\%; 'Harvest Queen', 41\%; 'Hearts of Gold', 33\%; and 'Topmark', 21\%.

In our early regeneration tests, we observed that most of the regenerated shoots developed from one of the four cut edges on the explant. Therefore, subsequent experiments were aimed to determine the relative regeneration efficiency of each edge. Three-day germinated cotyledons of each cultivar were cut into two or four pieces (Fig. 1) and monitored for shoot regeneration. The combined relative regeneration efficiencies for the cut edges of all cultivars are shown in Fig. 2. Proximal explants produced the highest percentage of regenerated shoots at their proximal edge, whereas distal explants produced significantly fewer shoots.

Shoot regeneration proceeded similarly from the cotyledons of all five cultivars. After 9 days, microscopic calli were observed on $\mathrm{RM}$, and, at 2 weeks, shoot primordia were visible. By the third week, a tight mass (Fig. 3) of as many as 50 to 75 shoot primordia (1 to $2 \mathrm{~mm}$ tall) had developed primarily all along the proximal edge of proximal explants or at one or more sites along that edge. However, on average, only about two to 10 shoots elongated per explant during the first 3 weeks that explants were observed. Shoots in liquid EM elongated faster and were generally greener than those grown on agar.

Shoots 0.5 to $1.0 \mathrm{~cm}$ were harvested for rooting by cutting down into the callus, which was then trimmed away from the shoot to lessen the possibility of propagating clones of the same transgenic line.

Melon transformation via A. tumefaciens. 'Burpee Hybrid,' 'Hales Best Jumbo', and 'Topmark' were selected for A. tumefaciens-mediated gene transfer experiments based on seed availability and economic importance. Three-day germinated cotyledons were cut into four pieces (Fig. 1B) for A. tumefaciens infections. Control explants (not inoculated with A. tumefaciens) cultured on nonselective media regenerated shoots at $82 \%$ and $89 \%$ for 'Burpee Hybrid' and 'Hales Best Jumbo,' respectively, while controls on selective media did not regenerate any shoots (Table 1 ). However, $24 \%$ and $18 \%$ of the A. tumefaciens-treated 'Burpee Hybrid' and 'Hales Best Jumbo' explants, respectively, produced shoots on selective media. Shoots that were regenerated from control and treated explants were rooted in nonselective or selective rooting media. Shoots were subsequently screened by X-gluc, and positive plants were regarded as being putatively transformed. No residual bacterial growth was recovered from sliced leaf tissue of putative transformed plants grown on amended LB medium (Sambrook et al., 1989). Putative transformed plants and regenerated controls from each cultivar were taken to the greenhouse to complete the cycle from regeneration to potted plant (Table 1). Additional tests, which are described later, confirmed that the putatively transformed plants were in fact transformed. The relative transformation efficiency was $0.9 \%$ for 'Burpee Hybrid' and $1 \%$ for 'Hales Best Jumbo' (Table 1). We did not obtain any transformed 'Topmark' shoots, due primarily to contamination (data not shown).

Melon transformation via microprojectile bombardment. Regeneration rates of explants that were bombarded while in the flat or apolar orientation are listed in Table 2. In nonselective medium, flat-oriented explants that were bombarded with buffer treated particles regenerated shoots at $76 \%(32 / 42)$, while similarly treated explants in the apolar orientation regenerated shoots at 84\% (37/ 44). Explants treated as above did not regenerate shoots on selective medium. However, flat-oriented explants that were bombarded with particles coated with vector plasmid pGA482GG/ cpCMV-WL initiated shoots at 57\% (135/235) on selective me- 
Table 1. Regeneration and relative Agrobacterium tumefaciens-mediated transformation efficiency ${ }^{\mathrm{z}}$ of 'Burpee Hybrid' and 'Hales Best Jumbo' muskmelon.

\begin{tabular}{|c|c|c|c|c|c|}
\hline \multirow[b]{3}{*}{ Treatment } & \multicolumn{2}{|c|}{ Explants } & \multicolumn{3}{|c|}{ Plants } \\
\hline & \multirow{2}{*}{$\begin{array}{c}\text { Total treated } \\
\text { (no.) }\end{array}$} & \multirow{2}{*}{$\begin{array}{c}\text { Regenerated } \\
(\%)\end{array}$} & \multicolumn{2}{|c|}{ Transformed $^{\mathrm{y}}$} & \multirow{2}{*}{$\begin{array}{l}\text { Greenhouse } \\
\text { plants }^{\mathrm{x}} \text { (no.) }\end{array}$} \\
\hline & & & (no.) & $(\%)$ & \\
\hline \multicolumn{6}{|c|}{ Burpee Hybrid } \\
\hline Agrobacterium treated & 446 & 24 & 4 & 0.90 & 70 \\
\hline \multicolumn{6}{|l|}{ Nontreated controls } \\
\hline On selection $^{\mathrm{w}}$ & 11 & 0 & 0 & 0.00 & 0 \\
\hline No selection & 39 & 82 & 0 & 0.00 & 12 \\
\hline \multicolumn{6}{|c|}{ Hales Best Jumbo } \\
\hline Agrobacterium treated & 196 & 18 & 2 & 1.0 & 27 \\
\hline \multicolumn{6}{|l|}{ Nontreated controls } \\
\hline On selection & 12 & 0 & 0 & 0.00 & 0 \\
\hline No selection & 48 & 89 & 0 & 0.00 & 12 \\
\hline
\end{tabular}

${ }_{\text {zRelative A. tumefaciens-mediated transformation efficiency (percentage transformed plants) is the number of transformed plants divided by the total }}$ number of explants treated.

${ }^{\mathrm{y}} \mathrm{R}_{0}$ plants that were positive by polymerase chain reaction for neomycin phosphotransferase II , $\beta$-glucuronidase, and cucumber mosaic virus-white leaf strain coat protein genes (Table 3).

${ }^{x}$ Includes transgenic and nontransgenic plants derived from $A$. tumefaciens-treated explants.

${ }^{w}$ Regeneration and elongation medium with selection contained kanamycin $(\mathrm{Km})$ at $150 \mathrm{mg} \cdot \mathrm{liter}^{-1}$ and rooting medium contained either no selection or $\mathrm{Km}$ at $50 \mathrm{mg} \cdot \mathrm{liter}^{-1}$.

Table 2. Regeneration and relative microprojectile-mediated transformation efficiency ${ }^{\mathrm{z}}$ of 'Topmark' muskmelon.

\begin{tabular}{|c|c|c|c|c|c|c|c|}
\hline \multirow[b]{3}{*}{ Treatment } & \multirow{3}{*}{$\begin{array}{c}\text { Explant } \\
\text { orientation }^{y}\end{array}$} & \multirow{3}{*}{$\begin{array}{c}\text { Flight } \\
\text { distance }^{\mathrm{x}}\end{array}$} & \multirow{3}{*}{$\begin{array}{l}\text { Total no. } \\
\text { explants }\end{array}$} & \multicolumn{4}{|c|}{ Explants } \\
\hline & & & & \multicolumn{2}{|c|}{ Regenerated } & \multicolumn{2}{|c|}{ Transformed } \\
\hline & & & & (no.) & $\overline{(\%)^{\mathrm{w}}}$ & $\overline{\text { (no.) }}$ & $(\%)$ \\
\hline \multicolumn{8}{|l|}{$\overline{\text { On selection }}$} \\
\hline \multirow[t]{6}{*}{ CMV-WL CP } & Flat & 1 & 118 & 74 & 63 & 0 & 0 \\
\hline & & 0 & 117 & 61 & 52 & 3 & 2.6 \\
\hline & & Total & 235 & 135 & 57 & 3 & 1.3 \\
\hline & Apolar & 1 & 123 & 91 & 74 & 2 & 1.6 \\
\hline & & 0 & 73 & 58 & 79 & 1 & 1.4 \\
\hline & & Total & 196 & 149 & 76 & 3 & 1.5 \\
\hline \multirow[t]{3}{*}{ Buffer } & Flat & 1 & 5 & 0 & 0 & 0 & 0 \\
\hline & Apolar & 1 & 5 & 0 & 0 & 0 & 0 \\
\hline & & Total & 10 & 0 & 0 & 0 & 0 \\
\hline \multicolumn{8}{|l|}{ On nonselection } \\
\hline \multirow[t]{6}{*}{ Buffer } & Flat & 1 & 23 & 20 & 87 & 0 & 0 \\
\hline & & 0 & 19 & 12 & 63 & 0 & 0 \\
\hline & & Total & 42 & 32 & 76 & 0 & 0 \\
\hline & Apolar & 1 & 19 & 16 & 84 & 0 & 0 \\
\hline & & 0 & 25 & 21 & 84 & 0 & 0 \\
\hline & & Total & 44 & 37 & 84 & 0 & 0 \\
\hline
\end{tabular}

${ }^{\mathrm{z}}$ Relative microprojectile-mediated transformation efficiency (percentage transformed explants ) is the number of explants producing transformed shoots divided by the total number of explants treated.

yPlacement in medium before bombardment.

${ }^{x}$ Distance $(\mathrm{cm})$ that a DNA-coated Kapton membrane must travel before hitting a stopping screen, which further propels DNA-coated tungsten particles into plant tissue.

wBased on the number of explants regenerating shoots at 3 weeks divided by the total number of explants. Although cucumber mosaic virus-white leaf strain coat protein-bombarded explants regenerated on selection, most of these shoots died after the third week. Totals are averages.

${ }^{\mathrm{v}} \mathrm{CMV}-\mathrm{WL} \mathrm{CP}=$ cucumber mosaic virus-white leaf strain coat protein.

dium, while similarly treated explants in the apolar position initiated shoots at 76\% (149/196) (Table 2). Although 284 DNAbombarded explants initiated shoots, only 12 of these actually produced elongated shoots that could be transferred to rooting medium. Forty-four shoots, positive in X-gluc or leaf callus tests on selective medium, were recovered from six of the 12 explants. One explant produced 35 positive shoots, another explant pro- duced three positive shoots, two explants produced two positive shoots each, and two explants produced one positive shoot each. Since these shoots were bombarded with DNA, getting positive results from contaminating bacteria was not a problem in this experiment. Thus, shoots that were positive in X-gluc or leaf callus tests were regarded as being transformed. Transformation efficiency was $2.6 \%$ for explants shot in the flat orientation at a 
Table 3. Characterization of $\mathrm{R}_{0}$ transgenic muskmelons. ${ }^{\mathrm{z}}$

\begin{tabular}{|c|c|c|c|c|c|c|c|c|c|c|c|c|c|c|}
\hline \multirow{2}{*}{$\begin{array}{l}\text { Transgenic } \\
\text { line }\end{array}$} & \multirow[b]{2}{*}{ Explant $^{\mathrm{v}}$} & \multirow{2}{*}{$\begin{array}{l}\text { X- } \\
\text { gluc }\end{array}$} & \multirow{2}{*}{$\begin{array}{l}\text { Leaf } \\
\text { callus }\end{array}$} & \multirow{2}{*}{$\begin{array}{l}\text { MUG } \\
\text { GUS }^{\mathrm{u}}\end{array}$} & \multicolumn{3}{|c|}{$\mathrm{PCR}^{\mathrm{y}}$} & \multicolumn{2}{|c|}{ ELISA $^{\mathrm{x}}$} & \multirow{2}{*}{$\begin{array}{c}\text { Western } \\
\text { blot }\end{array}$} & \multirow[b]{2}{*}{ Ploidy } & \multicolumn{3}{|c|}{ Morphology ${ }^{\mathrm{w}}$} \\
\hline & & & & & GUS & NPT II ${ }^{\mathrm{t}}$ & $\mathrm{CP}^{\mathrm{s}}$ & $\mathrm{CP}$ & NPT II & & & Leaf & Stem & Flower \\
\hline \multicolumn{15}{|c|}{ Agrobacterium tumefaciens-mediated transformation } \\
\hline \multicolumn{15}{|c|}{ Burpee Hybrid } \\
\hline M8-65 & $\mathrm{ND}^{\mathrm{r}}$ & + & + & - & + & + & + & - & $++/-{ }^{q}$ & $\mathrm{NT}^{\mathrm{p}}$ & $4 \mathrm{~N}$ & + & + & + \\
\hline M8-94 & ND & + & + & - & + & + & + & - & $+++/-$ & - & $4 \mathrm{~N}$ & + & + & + \\
\hline M8-97 & ND & - & + & - & + & + & + & - & +++ & NT & $4 \mathrm{~N}$ & + & + & + \\
\hline M8-98 & ND & - & + & - & + & + & + & - & $+/-$ & NT & $4 \mathrm{~N}$ & + & + & + \\
\hline \multicolumn{15}{|c|}{ Hales Best Jumbo } \\
\hline M13-8 & ND & + & + & + & + & + & + & ++++ & +++ & + & $4 \mathrm{~N}$ & - & + & - \\
\hline M13-56 & ND & + & + & + & + & + & + & ++++ & ++ & + & $4 \mathrm{~N}$ & - & + & - \\
\hline \multicolumn{15}{|c|}{ Microprojectile-mediated transformation } \\
\hline \multicolumn{15}{|l|}{ Topmark } \\
\hline TM-12 & $7 \mathrm{E}^{\mathrm{o}}$ & + & + & + & + & + & + & + & - & NT & NT & + & + & + \\
\hline TM-13 & $7 \mathrm{E}$ & + & + & + & + & + & + & ++ & - & NT & NT & + & + & + \\
\hline TM-15 & $7 \mathrm{E}$ & + & + & + & + & + & + & +++ & NT & - & $2 \mathrm{~N}$ & - & NT & + \\
\hline TM-17 & $7 \mathrm{E}$ & + & + & + & + & + & + & + & - & NT & $2 \mathrm{~N}+4 \mathrm{~N}$ & + & - & - \\
\hline TM-19 & $7 \mathrm{E}$ & + & + & + & + & + & + & + & - & NT & $2 \mathrm{~N}+4 \mathrm{~N}$ & + & + & + \\
\hline TM-21 & $7 \mathrm{E}$ & + & + & + & + & + & + & ++ & + & NT & $2 \mathrm{~N}$ & + & + & + \\
\hline TM-33 & $7 \mathrm{E}$ & + & - & - & - & + & + & - & NT & NT & $2 \mathrm{~N}+4 \mathrm{~N}$ & - & + & + \\
\hline TM-34 & $7 \mathrm{E}$ & + & + & + & + & + & + & ++ & - & - & $2 \mathrm{~N}+4 \mathrm{~N}$ & + & + & + \\
\hline TM-35 & $7 \mathrm{E}$ & + & - & + & + & + & + & + & - & NT & $2 \mathrm{~N}+4 \mathrm{~N}$ & + & + & + \\
\hline TM-36 & $7 \mathrm{E}$ & - & + & + & + & + & + & ++++ & - & - & $2 \mathrm{~N}+4 \mathrm{~N}$ & + & + & + \\
\hline TM-40 & $7 \mathrm{E}$ & - & + & - & + & + & + & - & + & NT & $2 \mathrm{~N}$ & + & - & + \\
\hline TM-75 & $7 \mathrm{E}$ & + & - & - & + & + & + & - & - & NT & NT & + & + & + \\
\hline TM-81 & $7 \mathrm{E}$ & - & + & - & + & + & + & ++ & NT & NT & NT & + & + & NT \\
\hline TM-44 & $8 B$ & - & + & - & + & + & + & - & NT & NT & $2 \mathrm{~N}$ & - & - & - \\
\hline TM-49 & $8 B$ & - & + & - & - & + & + & - & NT & - & $2 \mathrm{~N}$ & - & - & - \\
\hline TM-53 & $12 \mathrm{D}$ & - & + & + & + & + & + & + & + & NT & $2 \mathrm{~N}+4 \mathrm{~N}$ & - & - & - \\
\hline TM-56 & $12 \mathrm{D}$ & - & + & + & + & + & + & ++++ & + & - & $2 \mathrm{~N}+4 \mathrm{~N}$ & - & - & - \\
\hline
\end{tabular}

${ }^{\mathrm{z}}$ The six Agrobacterium tumefaciens-mediated putative transgenic plants and 17 out of 44 microprojectile bombarded transgenic plants were characterized.

yPCR $=$ polymerase chain reaction.

${ }^{x}$ ELISA = enzyme-linked immunosorbent assay. Expression level of cucumber mosaic virus-white leaf strain coat protein and neomycin phosphotransferase II was determined by ELISA at $\left(\mathrm{OD}_{405 \mathrm{~nm}}\right) .(-)$ is $0.07,(+)$ is 0.21 to $0.45,(++)$ is 0.46 to $0.70,(+++)$ is 0.71 to $0.95,(++++)$ is $>0.96$.

${ }^{\mathrm{w}}$ Observed leaf, stem, or flower morphologic variation compared to commercial plants is represented by + .

${ }^{v}$ Refers to specific explants that produced transgenic plants.

${ }^{\mathrm{u}} \mathrm{MUG}=4$-methylumbelliferyl $\beta$-D-glucuronide, GUS = $\beta$-glucuronidase .

${ }^{\mathrm{t} N P T}$ II = neomycin phosphotransferase II.

${ }^{\mathrm{s}} \mathrm{CP}=$ coat protein.

${ }^{\mathrm{r}}$ No data available.

${ }^{\mathrm{q}}$ Inconsistent test results are represented by +/-. For example, of seven NPT II ELISA tests done on M8-65, four were negative and three were positive. ${ }^{\mathrm{p}} \mathrm{NT}=$ Not tested.

${ }^{\circ} 7 \mathrm{E}, 8 \mathrm{~B}$, and $12 \mathrm{D}$ are three bombarded explants that regenerated the 17 shoots that were characterized.

macroprojectile flight distance of $0 \mathrm{~cm}$. No transformed plants were obtained from comparably oriented explants shot at a 1-cm flight distance (Table 2). Explants in the apolar orientation gave $1.6 \%$ and $1.4 \%$ transformation efficiency at 1 - and $0-\mathrm{cm}$ distances, respectively. Transgenic plants and controls were taken to the greenhouse for further testing and propagation.

Characterization of $R_{0}$ transformed plants for $C M V-W L C P$, NPT II, and GUS genes. Four A. tumefaciens-mediated putative transgenic 'Burpee Hybrid' and two 'Hales Best Jumbo' lines, as well as 17 of the 44 microprojectile-mediated transgenic 'Topmark' lines, were further characterized by GUS, ELISA, and PCR procedures. Also, eight plants were analyzed by western blot.

The PCR results showed that 21 of the 23 transgenic or putative transgenic lines that we characterized contained the GUS, CMVWL CP, and NPT II genes, while TM-33 and TM-49 contained only the NPT II and CMV-WL CP genes (Table 3, Fig. 4). These results showed that all of the 23 lines were indeed transgenic. In tests to detect the expression of these three genes, only 'Hales Best Jumbo' lines M13-8 and M13-56 showed consistent positive results (Table 3 ). On the other hand, the GUS gene was detected by PCR in all four transgenic 'Burpee Hybrid' lines, while corresponding tests to detect GUS expression (X-gluc and MUG tests) were mostly negative (Table 3 ). Likewise, the tests for NPT II gene expression (leaf callus, NPT II ELISA) gave conflicting results in some cases. For example, this was observed for TM-12 and TM36 (Table 3). Although PCR showed that all of the transgenic lines had the CMV-WL CP gene, all of the 'Burpee Hybrid' and some of the 'Topmark' lines were negative in CP ELISA. Although a limited number of plants were tested by western blot, consistent positive results were again only in the two 'Hales Best Jumbo' lines (Table 3, Fig. 5).

Ploidy analysis of $R_{0}$ plants. Flow cytometry data demonstrated 


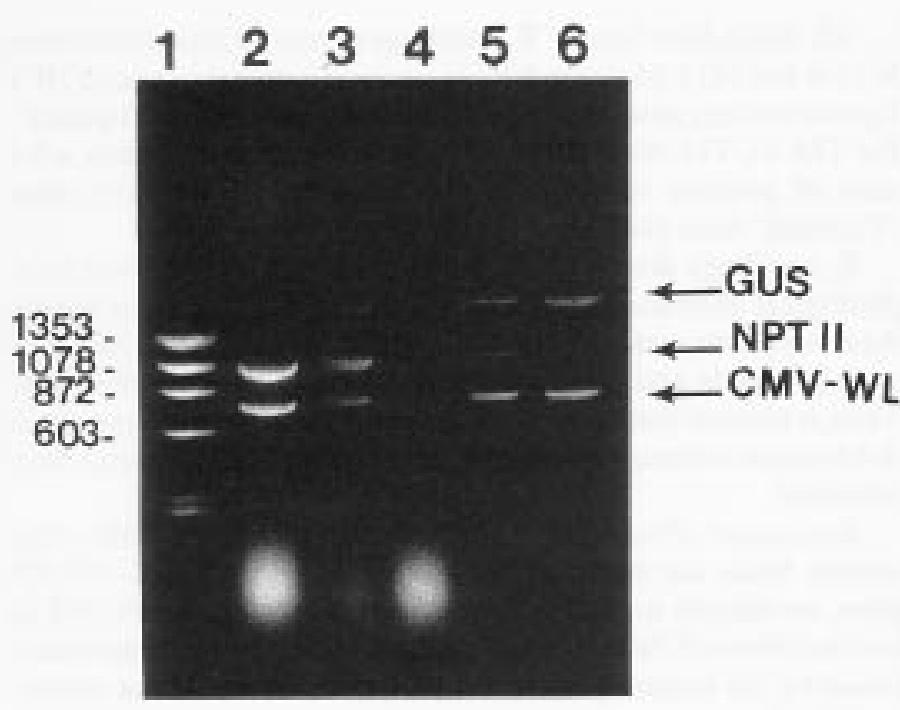

Fig. 4. Ethidium bromide-stained agarose gel showing the amplification by polymerase chain reaction (PCR) of the cucumber mosaic virus-white leaf strain coat protein (CP) (750 bp), neomycin phosphotransferase II (NPT II) (900 bp), and $\beta$-glucuronidase (GUS) (1670 bp) genes present in transgenic melon plants. All three genes were detected in all Agrobacterium tumefaciens-mediated transgenic lines (e.g., lane 5, M13-8, and lane 6, M8-65) and in all of the bombarded transgenic lines (e.g., lane 3, TM-34), except two lines that had only the NPT II and CP genes (e.g., lane 2, TM-33). Lane 1 corresponds to a molecular weight marker and lane 4 to a nontransgenic control.

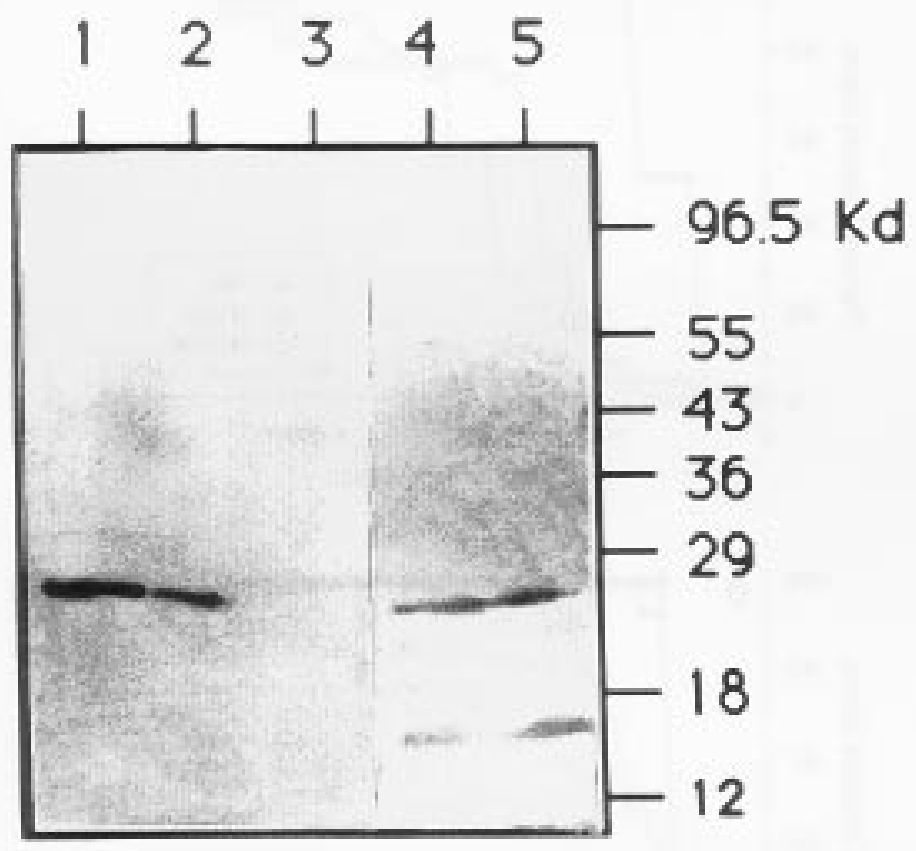

Fig. 5. Western analysis of cucumber mosaic virus-white leaf(CMV-WL) strain coat protein $(\mathrm{CP})$ in $\mathrm{R}_{0}$ transgenic muskmelon plants. Proteins extracted from 'Hales Best Jumbo' lines M13-8 (lane 4) and M13-56 (lane 5) were separated on a 12\% SDS-polyacrylamide gel, and CP was identified by immunoblot analysis. Lanes 1 and 2 show the position of purified CMV-WLCP ( 50 and $25 \mathrm{ng}$, respectively). Lane 3 corresponds to proteins extracted from a nontransformed plant.

that leaf tissue from all 'Burpee Hybrid' and 'Hales Best Jumbo' A. tumefaciens-mediated transgenic lines were tetraploid, while five 'Topmark' microprojectile-mediated transgenic lines tested were diploid and eight were mixoploid (diploid and tetraploid) (Table 3). Two nontransformed regenerants each were tested from 'Hales Best Jumbo' and 'Burpee Hybrid'. Each cultivar had one tetraploid and one diploid line. Interestingly, leaf tissue from each
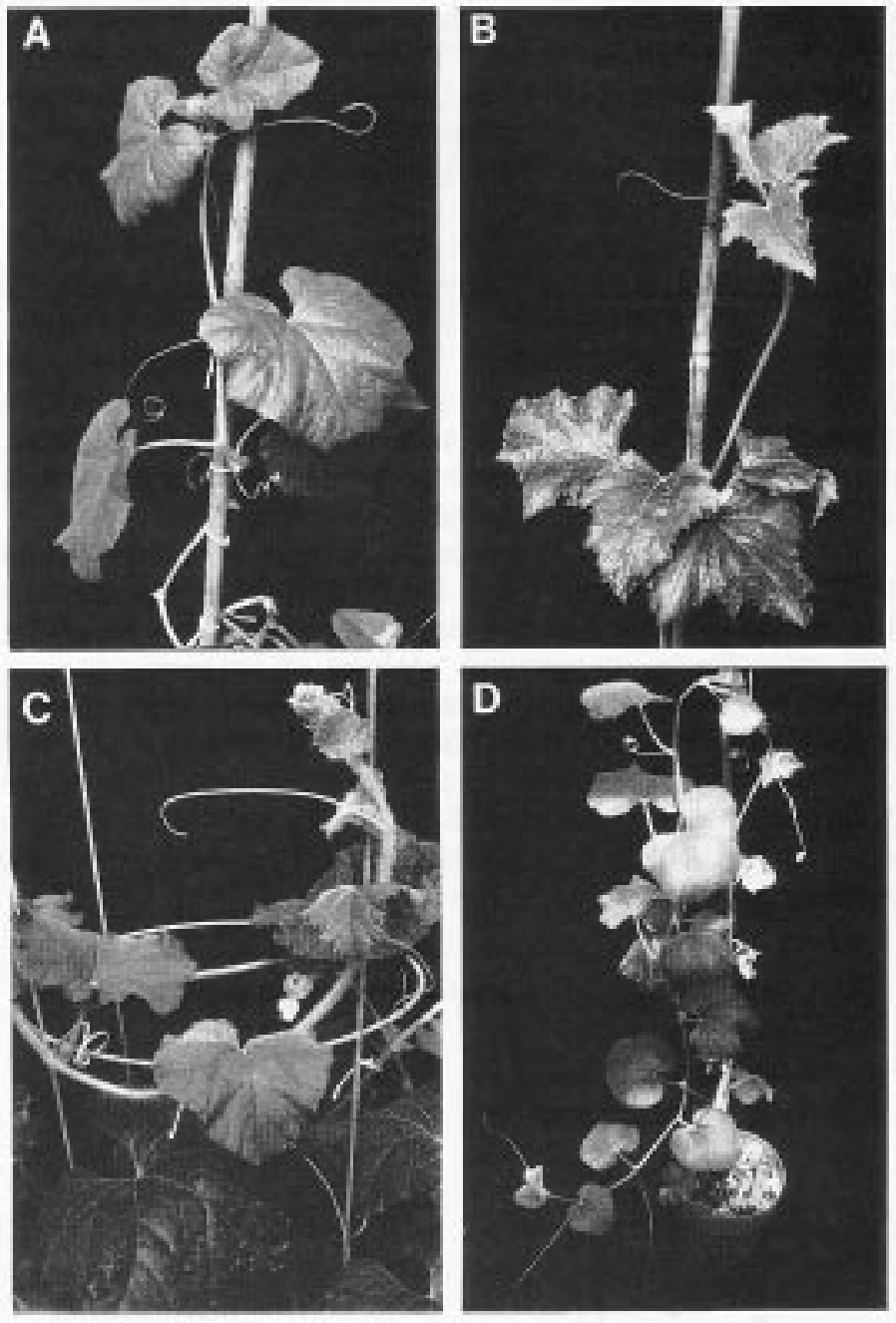

Fig. 6. 'Topmark' muskmelon $\mathrm{R}_{0}$ plants showing morphology of (A) regenerated nontransgenic plant with normal morphology, (B) transgenic TM-76 plant (not fully characterized as in Table 3) showing morphological variation of leavessharp-jagged edges, leaf clusters, and light-green patches (see lower left)—and a long internodal stem, (C) control 'Topmark' plant from commercial seed with normal morphology, and (D) leaves of transgenic TM-33 $\mathrm{R}_{0}$ clone without morphological variation.

of the three commercial cultivars was diploid; however, cells from the proximal edge of germinated cotyledon samples (Fig. 1A-2) were mixoploid (diploid, tetraploid, octoploid) (data not shown).

Morphology of $R_{0}$ plants. Compared to plants grown from commercial seeds, $\mathrm{R}_{0}$ transgenic plants and their vegetatively propagated cuttings nearly always showed at least some abnormality in the morphology of leaves, stems, or flowers, except for 'Topmark' plants from explants 8B and 12D (Table 3, Fig. 6). All 'Burpee Hybrid' lines had large flowers and anthers and leaf variation. Lines M8-94, M8-97, and M8-98 exhibited extreme somaclonal variation: some leaves were fan-shaped, had light green patches, or grew in clusters of about five leaves at one internode. At some locations along a stem, internodes were only $2.5 \mathrm{~cm}$ apart.

Somaclonal variation in $\mathrm{R}_{0}$ 'Hales Best Jumbo' appeared mainly as short internodes, as seen in 'Burpee Hybrid'. With 'Topmark', the abnormalities included leaves with heart- or maple-leaf shapes and light-green patches or jagged edges. Flowers were not abnormally large, but seven of the 14 plants observed had petals that were poorly spaced, out of line, or that had varying numbers of petals (Table 3 ). 
Pollinating $\mathrm{R}_{0}$ plants was difficult, with 'Burpee Hybrid' being the most problematic. In fact, 'Burpee Hybrid' seeds were obtained only from lines M8-65 and M8-97. The latter produced only two viable seeds. Both transgenic lines of 'Hales Best Jumbo' and all but two (TM-15 and TM-81) of the characterized 'Topmark' lines produced seeds.

During fruiting, unidentified yellow lesions formed over the entire surface of all but the youngest leaves of some transgenic and nontransgenic regenerated plants that had set fruit or were beginning to produce female flowers. These lesions appeared during a brief cold spell (15C) that occurred during summer on plants growing in two separate greenhouses. They were not virus related, as extract from these leaves did not produce local lesions on $C$. quinoa. Subsequent leaves did not have lesions.

Characterization of $R_{1}$ plants. $\mathrm{R}_{1}$ progeny were screened by NPT II ELISA to verify that the NPT II gene was sexually transmitted to seeds. This test was used because of its simplicity and reliability in our previous analyses of transgenic papaya, squash, and tomatoes (unpublished data). However, since 'Burpee Hybrid' yielded such a low number of NPT II-positive $\mathrm{R}_{0}$ plants ( 3 of 22 tested), PCR was applied to three $\mathrm{R}_{1}$ progeny to detect the presence of NPT II, GUS, and CMV-WL CP genes. Positive results in two of these three plants confirmed that these genes were sexually passed from the $\mathrm{R}_{0}$ line M8-65.
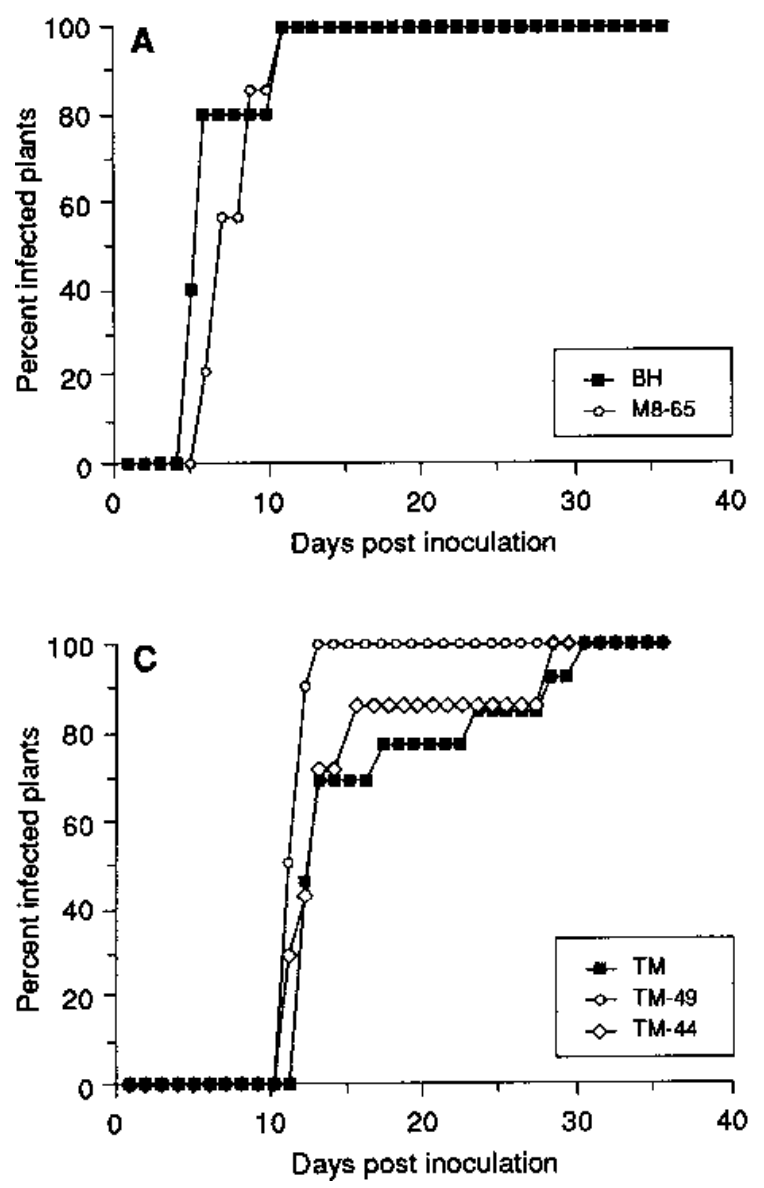

All 'Hales Best Jumbo' $\mathrm{R}_{1}$ seedlings tested (58 plants from lines M13-8 and M13-56) were NPT II positive, while the ratio of NPT II positive to negative seedlings differed between lines of 'Topmark'. For TM-44, TM-49, and TM-53 (290 seedlings tested) lines, a 3:1 ratio of positive to negative plants was observed. Five other 'Topmark' lines (441 plants) were negative.

$\mathrm{R}_{1}$ seedlings derived from $\mathrm{R}_{0}$ plants sometimes showed morphological aberrations, such as malformed cotyledons or leaves. As these plants matured, short internodes and clustering of leaves at an internode and fan-shaped leaves were sometimes observed. Thus, it seemed that the somaclonal variations that may have been due to tissue culture, explant type, or selection-pressure stress were inherited.

Resistance of transgenic plants to inoculation by $C M V-F N Y$ isolate. Since our transgenic plants contained the CMV-WL CP gene, we initially inoculated clones of $\mathrm{R}_{0}$ plants with CMV-WL to test the effect of CMV-WLCP-mediated protection against inoculation by the homologous virus. However, we could not consistently infect our control plants, even after two or three inoculations with CMV-WL-infected squash extracts that produced more than 100 local lesions per leaf on C. quinoa. On the other hand, we could consistently infect our melon cultivars with another CMV strain, designated CMV-FNY, that was originally recovered from melons (Banik and Zitter, 1990). This virus strain aggressively infects
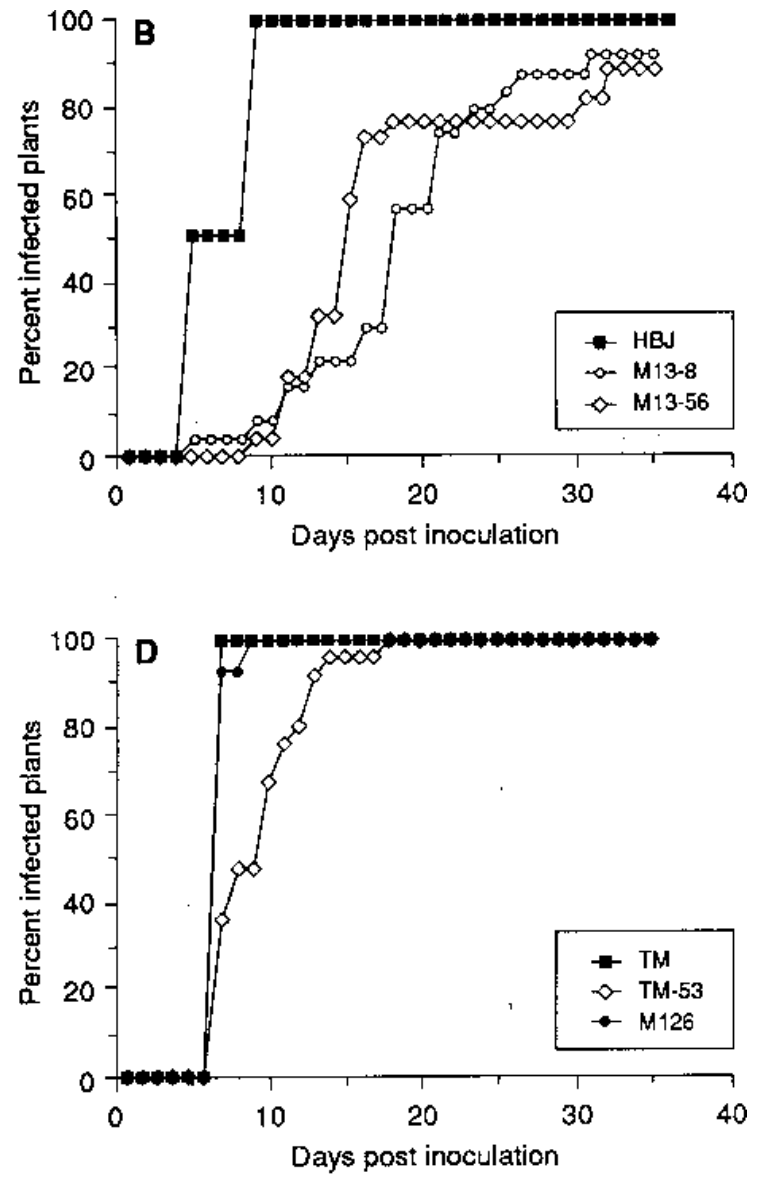

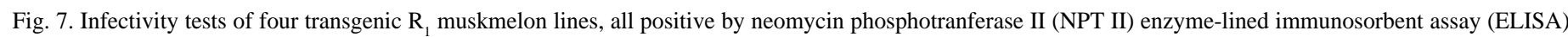

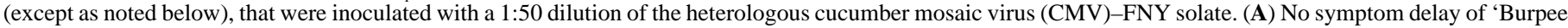

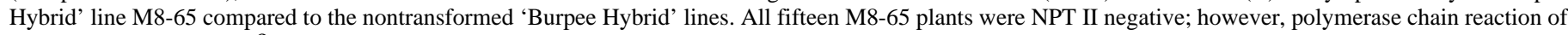

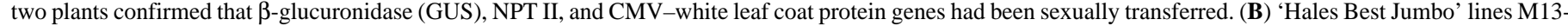

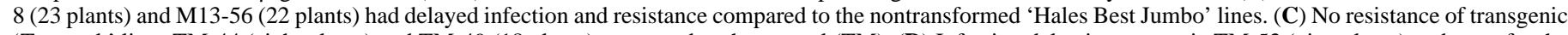

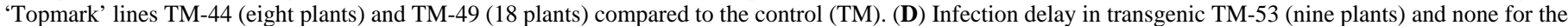
nontransformed M126 control. Number of control plants per inoculated line ranged from five to 22. 
melons and squash, is well characterized (Palukaitis et al., 1992), and is routinely maintained on melons (T. Zitter, personal communication). Therefore, all inoculations of $\mathrm{R}_{1}$ plants were made with CMV-FNY.

Seedlings used in the infectivity tests were from one transgenic line of 'Burpee Hybrid', two of 'Hales Best Jumbo', three of 'Topmark', and nontransformed control plants (Fig. 7). The $\mathrm{R}_{1}$ plants were first screened by NPT II ELISA, then inoculated with CMV-FNY. Inoculated plants were rated as infected when systemic symptoms were first observed. The results (Fig. 7) show clear differences in the level of CPMP among these transgenic lines. Of the A. tumefaciens-transformed cultivars, the $\mathrm{R}_{1}$ plants from the non-CP-expressing transgenic 'Burpee Hybrid' (M8-65) line did not show any resistance compared to similarly inoculated plants of nontransformed 'Burpee Hybrid'. All of these controls and transgenic plants were symptomatic 11 days after the first inoculation (Fig. 7A). On the other hand, $\mathrm{R}_{1}$ plants from the two CP-expressing lines of 'Hales Best Jumbo' (M13-8 and M13-56) had delayed symptom development or were resistant. For example, 9 days after inoculation, $100 \%$ of the control plants vs. only $7 \%$ of the transgenic 'Hales Best Jumbo' were symptomatic. Sixty-nine percent of the transgenic plants became infected between 11 and 21 days postinoculation, and, 31 days after inoculation all but five of the 45 inoculated transgenic plants showed symptoms (Fig. 7B). The five resistant plants have remained nonsymptomatic for more than 6 months postinoculation and are being held for seed production. Tissue extracts from these plants did not produce lesions on $C$. quinoa, a result indicating the absence of latent infection. $\mathrm{R}_{1}$ plants of 'Topmark' lines TM-44 and TM-49 became infected as fast or faster than the controls (Fig. 7C), whereas those of line TM-53 had delayed symptom development (Fig. 7D).

Symptoms that developed on transgenic plants were similar to those observed on nontransgenic control plants. Plants that became infected showed downward curling and yellow spots or mosaic symptoms on uninoculated leaves. Occasionally, the inoculated leaves also showed downward curling and yellow spots. Stunting sometimes occurred before leaf symptoms, but most plants grew normally until systemic symptoms appeared, at which time plant growth ceased. Extracts from symptomatic leaves produced abundant local lesions on $C$. quinoa, a result confirming that the observed symptoms were associated with CMV infection (data not shown).

\section{Discussion}

In our regeneration studies, shoot induction of 'Burpee Hybrid', 'Hales Best Jumbo', 'Hearts of Gold', 'Harvest Queen', and 'Topmark' was obtained with Dirks and Van Buggenum medium (1989). Previously, Dirks and Van Buggenum (1989) had regenerated five other melon cultivars: Accent, Galia, 4215, Preco, and Viva. Our work expands the number of genotypes that can be regenerated from this medium. Hence, this medium seems to be broadly applicable for melon genotypes and, therefore, useful for A. tumefaciens and microprojectile transformations.

However, our regeneration protocol differs from Dirks and Van Buggenum's (1989) in several ways. First, sterilized, peeled seeds were germinated on moist filter paper for 4 days; second, all of our media contained $\mathrm{Cb}$ at $500 \mathrm{mg} \cdot$ liter $^{-1}$; third, liquid medium with reduced BA was used to enhance shoot elongation; and fourth, young germinated cotyledons were used for shoot regeneration. Shoots could be consistently regenerated from germinated cotyledons and from cotyledons extracted from mature seeds, but not from leaves, as Dirks and Van Buggenum (1989) reported. Since we were not successful in transforming mature seed explants, young germinated cotyledons were eventually used in all of our experiments. Our study of five cultivars showed that shoot regeneration was most prolific from the proximal edge of cotyledon explants (Fig. 2). These results confirm those reported by Leshem (1989).

In the transformation experiments, the NPT II, GUS, and CMV-WL CP genes were transferred into the genome of three melon cultivars using two different methods for gene transfer: $A$. tumefaciens and microprojectile bombardment. However, we cannot compare the relative transformation efficiency of these methods due to the use of different cultivars and explant preparation.

Our results indicate that more than one test should be used to characterize plants that have gone through the transformation process. NPT II ELISA and X-gluc tests (each requiring as little as $12 \mathrm{mg}$ of leaf sample) can commence when plants are in tissue culture. In addition, leaf callus tests require small amounts of tissue and can be used for in vitro cultures, although these types of results are sometimes difficult to rate. Plants that test positive in tissue culture should also be tested after they are established in the greenhouse. These tests could include PCR, which requires larger amounts of actively growing tissue for DNA extraction. ELISA can be also used to detect CP expression, but, as shown in Table 3 , a number of transgenic plants do not produce detectable levels of $\mathrm{CP}$. We have not explored the GUS (MUG) assay enough to determine its effectiveness in melons.

We observed a number of morphological abnormalities in our transgenic plants. Although severe plant deformations were rare, closer inspection of in vitro transgenic plants revealed, for example, plants without apical dominance. In the greenhouse, we also observed stem, leaf, and flower abnormalities. Of the $\mathrm{R}_{0}$ lines characterized, all 'Burpee Hybrid' and 'Hales Best Jumbo' and $>76 \%$ of 'Topmark' lines had one or more characteristics that differed from plants grown from commercial seeds. Contrary to our findings, morphologically abnormal plants have not been reported in other cucurbit transformations (Chee, 1990b; Chee and Slightom, 1992; Dong et al., 1991; Fang and Grumet, 1990; Trulson et al., 1986; Yoshioka et al., 1992). Trulson et al. (1986) however, mentioned that, although no leaf abnormalities were seen, some transgenic cucumber plants had thicker leaves and shorter internodes, and reducing $\mathrm{Km}$ from 50 to $25 \mathrm{mg} \cdot \mathrm{liter}^{-1}$ reduced the amount of abnormalities. Our level of $\mathrm{Km}$ in selective media $\left(150 \mathrm{mg} \cdot\right.$ liter $\left.^{-1}\right)$ was 1.2 to 3 times higher than those reported in other studies. According to Trulson et al. (1986), it is likely that a high rate of $\mathrm{Km}$ selection caused changes in plant morphology. However, other factors may include tissue stress caused by the tissue-culture regeneration process and other chemicals such as BA (Larkin and Scowcroft, 1981).

Our study confirmed previous reports showing that tetraploid melon plants could be generated in tissue culture (Adelberg et al., 1990; Ezura et al., 1991). Although the shoot-regeneration process and chemicals used in tissue culture can contribute to this change, other factors may be involved. For example, flow cytometer analysis showed that leaves from commercial seeds of 'Burpee Hybrid', 'Hales Best Jumbo', and 'Topmark' were diploid, whereas tissue from the proximal area (Fig. 1 A-2, B-3, and B-4) of germinated cotyledons was mixoploid (diploid, tetraploid, octoploid). Similar differences in ploidy level among cotyledons and leaf tissue have been reported previously for $C$. sativus (ColijnHooymans et al., 1988). Since our melon shoots were regenerated from cotyledons, they could have arisen from either diploid, tetraploid, or octoploid cells. Nevertheless, even diploid regener- 
ated plants can show morphologic variation, as seen in 'Topmark' shoots produced by explant 7E (Table 3 ).

Pollination proved difficult during the first year, but for plants that bore fruit, sexual transmission of some of the abnormal characters was evident in $\mathrm{R}_{1}$ seedlings, in which deformed cotyledons and leaves were seen occasionally. In an effort to pollinate recalcitrant $R_{0}$ plants, new cuttings were made to replace the old ones. Pollination success increased with experience and was helped by applying a BA emulsion to the base of ovaries (Munger and Lane, 1983).

As far as we know, no one has reported on the development of transgenic melons that contain the CMV-WL CP gene. We chose to use the CMV-WL CP gene because our work in tobacco (Namba et al., 1991), squash, and tomato (unpublished data) showed that plants containing this gene construction possess a high level of resistance to the homologous CMV-WL, a member of subgroup II (Palukaitis et al., 1992), as well as to strains from subgroup I, including CMV-FNY for tomatoes (unpublished data). However, our transgenic melons containing the CMV-WL CP gene generally did not show high levels of resistance to inoculations by CMV-FNY when compared to our other transgenic crops such as tomatoes and squash (unpublished data). We did not test the resistance of our transgenic melons to the homologous virus because CMV-WL did not readily cause systemic infection in melons. Our resistance studies of $\mathrm{R}_{1}$ melons showed a delay in infection in 'Hales Best Jumbo' and 'Topmark', but not in 'Burpee Hybrid'. Five 'Hales Best Jumbo' plants seem to be resistant to CMV-FNY infection and they are being propagated to the $\mathrm{R}_{2}$ generation for future testing. It is interesting to note that only plants from the $\mathrm{CP}$-expressing lines had delayed symptom expression or resistance. However, our data are too preliminary to determine if the level of CP expression in melons is correlated to delayed symptom expression or resistance.

It is conceivable that screening more transgenic melon lines will reveal more lines that are resistant to CMV. It may also be possible that CPMP in melons is inherently more difficult than for other plant species (Fitch et al., 1992; Namba et al., 1991). Perhaps using the CMV replicase gene (Anderson et al., 1992) may provide better protection in melons. More transgenic melons with a variety of viral genes need to be produced and tested to obtain virusresistant plants via genetic engineering.

Meanwhile, since CMV-WL is easily transmitted by aphids, we will use the susceptible transgenic melons as models in riskassessment experiments to determine whether transgenic plants expressing the $\mathrm{CP}$ gene (CMV-WL) of an aphid-transmissible isolate could help disperse nonaphid-transmissible CMV isolates through heterologous encapsidation (DeZoeten, 1991). For example, field experiments will be set up to determine whether transgenic 'Topmark' infected with CMV-C, a nonaphid-transmissible isolate (Quemada et al., 1991), can serve as sources for transmission of $\mathrm{CMV}-\mathrm{C}$ to other melons.

\section{Literature Cited}

Adelberg, J.W., B.B. Rhodes, and H.T. Skorupska. 1990. Generating tetraploid melons from tissue culture. HortScience 25:1073. (Abstr.)

Anderson, J.M., P. Palukaitis, and M. Zaitlin. 1992. A defective replicase gene induces resistance to cucumber mosaic virus in transgenic tobacco plants. Proc. Natl. Acad. Sci. 89:8759-8763.

Arumuganathan, K. and E.D. Earle. 1991. Estimation of nuclear DNA content of plants by flow cytometry. Plant Mol. Biol. Rpt. 9(3):229-233.

Banik, M.T. and T.A. Zitter. 1990. Determination of cucumber mosaic virus titer in muskmelon by enzyme-linked immunosorbent assay and correlation with aphid transmission. Plant Dis. 74:857-859.
Beachy, R.N., S. Loesch-Fries, and N.E. Tumer. 1990. Coat proteinmediated resistance against virus infection. Annu. Rev. Phytopathol. 28:451-474.

Chee, P.P. 1990a. High frequency of somatic embryogenesis and recovery of fertile cucumber plants. HortScience 25:792-793.

Chee, P.P. 1990b. Transformation of Cucumis sativus tissue by Agrobacterium tumefaciens and the regeneration of transformed plants. Plant Cell Rpt. 9:245-248.

Chee, P.P. 1991a. Plant regeneration from cotyledons of Cucumis melo 'Topmark'. HortScience 26:908-910.

Chee, P.P. 1991b. Somatic embryogenesis and plant regeneration of squash Cucurbita pepo L. cv. YC 60. Plant Cell Rpt. 9:620-622.

Chee, P.P. 1992. Initiation and maturation of somatic embryos of squash (Cucurbito [sic] pepo). HortScience 27:59-60.

Chee, P.P. and J.L. Slightom. 1991. Transfer and expression of cucumber mosaic virus coat protein gene in the genome of Cucumis sativus. J. Amer. Soc. Hort. Sci. 116:1098-1102.

Chee, P.P. and J.L. Slightom. 1992. Transformation of cucumber tissues by microprojectile bombardment: Identification of plants containing functional and non-functional transferred genes. Gene 118:255-260.

Colijn-Hooymans, C.M., R. Bouwer, and J.J.M. Dons. 1988. Plant regeneration from cucumber protoplasts. Plant Cell Tissue Organ Cult. 12:147-150.

Dellaporta, S.L., J. Wood, and J.B. Hicks. 1985. Maize DNA miniprep, p. 3-37. In: R. Malmberg, J. Messing, and I. Sussex (eds.). Molecular biology of plants. Cold Spring Harbor Laboratory, Cold Spring, N.Y.

DeZoeten, G.A. 1991. Risk assessment: Do we let history repeat itself? Phytopathology 81:585-586.

Dirks, R. and M. Van Buggenum. 1989. In vitro plant regeneration from leaf and cotyledon explants of Cucumis melo L. Plant Cell Rpt. 7:626627.

Dong, J.Z., M.Z. Yang, S.R. Jia, and N.H. Chua. 1991. Transformation of melon (Cucumis Melo L.) and expression from the cauliflower mosaic virus $35 \mathrm{~S}$ promoter in transgenic melon plants. Bio/Technology 9:858863.

Edwards, M.C. and D. Gonsalves. 1983. Grouping of seven biologically defined isolates of cucumber mosaic virus by peptide mapping. Phytopathology 73:1117-1120.

Enzie, W.D. 1943. A source of muskmelon mosaic resistance found in the oriental pickling melon, Cucumis melo var. connomon. Proc. Amer. Soc. Hort. Sci. 43:195-198.

Ezura, H., H. Amagai, K. Yoshioka, and K. Oosawa. 1991. Efficient production of tetraploid melon Cucumis melo L. by somatic embryogenesis. Jpn. J. Breeding 42(1):137-144.

Fang, G. and R. Grumet. 1990. Agrobacterium tumefaciens mediated transformation and regeneration of muskmelon plants. Plant Cell Rpt. 9:160-164.

Fitch, M.M.M., R.M. Manshardt, D. Gonsalves, J.L. Slightom, and J.C. Sanford. 1992. Virus resistant papaya plants derived from tissues bombarded with the coat protein gene of papaya ringspot virus. Bio/ Technology 10:1466-1472.

Food and Agriculture Organization of the United Nations. 1990. Yearbook. Production. vol. 44. Food and Agr. Organization, Rome.

Gonsalves, D., P. Chee, R. Provvidenti, R. Seem, and J.L. Slightom. 1992. Comparison of coat protein-mediated and genetically derived resistance in cucumbers to infection by cucumber mosaic virus under field conditions with natural challenge inoculations by vectors. Bio/Technology 10:1562-1570

Hepburn, A.G., J. White, L. Pearson, M.J. Maunders, L.E. Clarke, A.G. Prescott, and K.S. Blundy. 1985. The use of pNJ5000 as an intermediate vector for the genetic manipulation of Agrobacterium Ti-plasmids. J. Gen. Microbiol. 131:2961-2969.

Jefferson, R.A. 1987. Assaying chimeric genes in plants: The GUS gene fusion system. Plant Mol. Biol. Rpt. 5:387-405.

Jelaska, S. 1974. Embryogenesis and organogenesis in pumpkin explants. Physiol. Plant. 31:257-263.

Kado, C.I., M.G. Heskett, and R.A. Langley. 1972. Studies on Agrobacterium tumefaciens: Characterization of strains 1D135 and B6, and analysis of the bacterial chromosome, transfer RNA and ribosomes for 
tumor inducing ability. Physiol. Plant Pathol. 2:47-57.

Kathal, R., S.P. Bhatnagar, and S.S. Bhojwani. 1989. Regeneration of plants from leaf explants of Cucumis melo cv. Pusa Sharbati. Plant Cell Rpt. 7:449-451.

Laemmli, U.K. 1970. Cleavage of structural proteins during the assembly of the head of bacteriophage T4. Nature 227:680-685.

Larkin, P.J. and W.R. Scowcroft. 1981. Somaclonal variation-A novel source of variability from cell cultures for plant improvement. Theoretical Applied Genet. 60:197-214.

Leshem, B. 1989. Polarity and responsive regions for regeneration in the cultured melon cotyledon. J. Plant Physiol. 135:237-239.

Ling, K., S. Namba, C. Gonsalves, J.L. Slightom, and D. Gonsalves. 1991. Protection against detrimental effects of potyvirus infection in transgenic tobacco plants expressing the papaya ringspot virus coat protein gene. Bio/Technology 9:752-758.

McCabe, D.E., W.F. Swain, B.J. Martinell, and P. Christou. 1989. Stable transformation of soybean (Glycine max) by particle acceleration. Bio/ Technology 6:923-926.

Moreno, V., M. Garcia-Sogo, I. Granell, B. Garcia-Sogo, and L.A. Roig. 1985. Plant regeneration from calli of melon (Cucumis melo L., cv. 'Amarillo Oro'). Plant Cell Tissue Organ Cult. 5: 139-146.

Munger, H.M. 1985. Near-isogenic lines of several cucumber varieties. Cucurbit Genet. Coop. Rpt. 8:4-6.

Munger, H.M. and D.P. Lane. 1983. An improved method of BA application for the promotion of fruit set in muskmelon. Cucurbit Genet. Coop. Rpt. 6:4-6.

Murashige, T. and F. Skoog. 1962. A revised medium for rapid growth and bioassays with tobacco tissue cultures. Physiol. Plant. 15:473-497.

Namba, S., K. Ling, C. Gonsalves, D. Gonsalves, and J.L. Slightom. 1991. Expression of the gene encoding the coat protein of cucumber mosaic virus (CMV) strain WL appears to provide protection to tobacco plants against infection by several different CMV strains. Gene 107:181-188.

Namba, S., K. Ling, C. Gonsalves, J.L. Slightom, and D. Gonsalves. 1992. Protection of transgenic plants expressing the coat protein gene of watermelon mosaic virus II or zucchini yellow mosaic virus against six potyviruses. Phytopathology 82:940-946.

Oridate, T. and K. Oosawa. 1986. Somatic embryogenesis and plant regeneration from suspension callus culture in melon (Cucumis melo L.). Jpn. J. Breeding 36:424-428.

Palukaitis, P., M.J. Roossinck, R.G. Dietzgen, and R.I.B. Francki. 1992. Cucumber mosaic virus, p. 281-348. In: K. Maramorosch, F.A. Murphy, and A.J. Shatkin (eds.). Advances in virus research. Academic Press, San Diego.

Pierce, L.K. and T.C. Wehner. 1990. Review of genes and linkage groups in cucumber. HortScience 25:605-615.

Quemada, H.D., D. Gonsalves, and J.L. Slightom. 1991. Expression of a coat protein gene from cucumber mosaic virus strain $\mathrm{C}$ in tobacco: Protection against infections by CMV strains transmitted mechanically or by aphids. Phytopathology 81:794-802.

Robinson, R.W., T.C. Wehner, J.D. McCreight, W.R. Henderson, and C.A. John. 1982. Update of the cucurbit gene list and nomenclature rules. Cucurbit Genet. Coop. 5:62-66.

Sambrook, J., E.F. Fritsch, and T. Maniatis. 1989. Molecular cloning: A laboratory manual. 2nd ed. Cold Spring Harbor Laboratory Press, Cold Spring Harbor, N.Y.

Sanford, J.C., F.D. Smith, and J.A. Russell. 1992. Optimizing the biolistic process for different biological applications. Methods Enzymol. 217:483509.

Stark, D.M. and R.N. Beachy. 1989. Protection against potyvirus infection in transgenic plants: Evidence for broad spectrum resistance. Bio/ Technology 7:1257-1262.

Tomlinson, J.A. 1987. Epidemiology and control of virus diseases of vegetables. Ann. Applied Biol. 110:661-681.

Trulson, A.J., R.B. Simpson, and E.A. Shahin. 1986. Transformation of cucumber (Cucumis sativus L.) plants with Agrobacterium rhizogenes. Theoretical Applied Genet. 73:11-15.

Wehner, T.C. and R.W. Robinson. 1991. A brief history of the development of cucumber cultivars in the U.S. Cucurbit Genet. Coop. Rpt. 14:1.

Yoshioka, K., K. Hanada, Y. Nakazaki, Y. Minobe, T. Yakuwa, and K. Oosawa. 1992. Successful transfer of the cucumber mosaic virus coat protein gene to Cucumis melo L. Jpn. J. Breeding 42(2):278-285.

Zitter, T.A. and D. Gonsalves. 1991. Differentiation of pseudorecombinants of two cucumber mosaic virus strains by biological properties and aphid transmission. Phytopathology 81:139-143. 